\title{
EVALUASI PROMOSI DAN PELATIHAN HIGIENE DAN SANITASI PENJAMAH MAKANAN DI KANTIN SEKOLAH
}

\author{
Evaluation of Hygiene and Sanitation Promotion and Training \\ for Food Handler in School Cafetaria
}

\author{
${ }^{1}$ Nirmala Tri Kartika, ${ }^{1}$ Nurnaningsih Herya Ulfah \\ Prodi Ilmu Kesehatan Masyarakat Fakultas Ilmu Keolahragaan \\ Universitas Negeri Malang \\ Email: ntkartika@gmail.com,nurnaherya.fik@um.ac.id
}

\begin{abstract}
The Long Term Development Plan (2005-2024) focuses on health development towards a promotive and preventive health effort with one of its programs called Gerakan Masyarakat Sehat (Germas). This program is expected to increase everyone's knowledge, awareness, willingness and ability to live healthy. One of the activities of Malang City Health Office to succeed the program is by training and Counseling of Hygiene and Sanitation for food handlers in School Canteen. for food handlers in School Canteen. The activity requires evaluation because the result of posttest score of participants is an average of 60 . The results are influenced by participants who are not present continuously. This study aims to describe $6 M$ component (material, money, machine, methode, man, and, measure). The research method used observation which used 6M component. In this activity there are 9 problems such as no material handout, budget adjusting with Malang city budget, fast discharging microphone batteries, some participants not present continuously, exposure only with lectures, not accompanied by training practices, inappropriate targets, and lack of organizing committee And low posttest results. 5 out of 9 such problems are given alternative problem solving such as arranging the rundown of the event, the speaker practice the material that he explained, briefing the coordinator of the puskesmas that will spread the invitation, and arrange the organizing committee which involves one field.
\end{abstract}

Keywords: Training and Counseling, Food Handlers, Evaluation

\begin{abstract}
Abstrak
Rencana Pembangunan Jangka Panjang (2005-2024) fokus pada pembangunan kesehatan menuju ke arah upaya kesehatan promotif dan preventif dengan salah satu programnya adalah Gerakan Masyarakar Sehat (Germas).Program ini diharapkan dapat meningkatkan pengetahuan, kesadaran, kemauan dan kemampuan hidup sehat bagi setiap orang.Salah satu kegiatan Dinas Kesehatan Kota Malang untuk mensukseskan program tersebut ialah dengan kegiatan Pelatihan dan Penyuluhan Higiene dan Sanitasi Bagi Penjamah Makanan dan Minuman Kantin Sekolah.Kegiatan tersebut memerlukan evaluasi sebab hasil nilai posttest peserta rata-rata 60.Hasil tersebut dipengaruhi oleh peserta yang tidak hadir secara kontinu.Penelitian ini bertujuan untuk mendiskripsikan komponen 6M (material, money, machine, methode, man, dan, measure).Metode penelitian menggunakan observasi yang kemudian di evaluasi dengan komponen 6M. Pada kegiatan tersebut terdapat 9 ${ }^{1}$ Nirmala Tri Kartika dan Nurnaningsih Herya Ulfah adalah Prodi Ilmu Kesehatan Masyarakat Fakultas Ilmu KeolahragaanUniversitas Negeri Malang
\end{abstract}


masalah diantaranya tidak ada handout materi, anggaran yang menyesuaikan APBD Kota Malang, baterai microphone yang cepat habis, beberapa peserta tidak hadir secara kontinu, pemaparan hanya dengan ceramah, tidak disertai praktik pelatihan, sasaran kurang tepat, dan kurangnya panitia penyelenggara dan hasil posttest yang rendah. 5 dari 9 masalah tersebut diberikan alternatif pemecahan masalah diantaranya menyusun rundown acara, pemateri mempraktikan materi yang disampaikan, melakukan briefing pada koordinator puskesmas yang akan menyebarkan undangan, dan menyusun panitia penyelenggara yang melibatkan satu bidang.

Kata Kunci:Pelatihan dan Penyuluhan, Penjamah Makanan,Evaluasi

\section{PENDAHULUAN}

Suatu masyarakat yang memiliki pengetahuan higiene dan sanitasi makanan yang rendah cenderung beresiko terkena atau tertular suatu penyakit. Berdasarkan hasil penelitian yang dilakukan oleh Maharani sebesar $61,54 \%$ higiene dan sanitasi penjamah makanan SMAN 3 Wonogiri tidak memenuhi syarat kesehatan, hal ini dikarenakan para penjamah tidak memperhatikan tentang personal higiene, mereka berjualan dengan merokok, memakai perhiasan di tangannya (penjual perempuan), padahal dalam aturan tidak diperbolehkan. ${ }^{1}$

Selain itu Kesalahan penyiapan makanan yang di sertai dengan personal higiene buruk dalam mengolah makanan dan penyimpanannya menyebabkan pertumbuhan bakteri pathogen. Bakteri pathogen ialah bakteri penyebab diare, seperti Coliform (Eschercia coli, Enteribacter arogenes), Shigella spp, Salmonella app, dan Virbrio cholereae. ${ }^{2}$

Rencana Pembangunan Jangka

Panjang (2005-2024) fokus pada pembangunan kesehatan menuju ke arah upaya kesehatan promotif dan preventif. Salah satu program Kementerian Kesehatan (Kemenkes) RI dalam rencana pembangunan tersebut adalah Gerakan Masyarakat hidup Sehat (Germas). Tahun ini Germas difokuskan pada: 1)
Melakukan aktivitas fisik, 2) Mengonsumsi sayur dan buah dan 3) Memeriksa kesehatan secara rutin. Program Germas diharapkan dapat meningkatkan pengetahuan, kesadaran, kemauan dan kemampuan hidup sehat bagi setiap orang. ${ }^{3}$

Dinas Kesehatan Kota Malang merupakan perangkat daerah yang melaksanakan urusan pemerintahan daerah di bidang kesehatan.Salah satu program dalam mensukseskan Germas ialah menciptakan lingkungan yang sehat. Kegiatan yang ada di program tersebut diantaranya Penyuluhan Higiene dan Sanitasi Bagi Penjamah Makanan dan Minuman PKL di Pasar Senggol, Penyuluhan Higiene dan Sanitasi Bagi Penjamah Makanan dan Minuman PKL di Sekitar Sekolah, dan Penyuluhan Higiene dan Sanitasi Bagi Penjamah Makanan dan Minuman Rumah Makan/Resto/Depot/ Catering dan Pelatihan dan Penyuluhan Higiene dan Sanitasi Bagi Penjamah Makanan dan Minuman Kantin SD/SMP/SMA/Sederajat.

Pada kegiatan Pelatihan dan Penyuluhan Higiene dan Sanitasi Bagi Penjamah Makanan dan Minuman Kantin SD/SMP/SMA/Sederajat terdapat hasil posttest dengan nilai rata-rata sebesar 60.Hasil tersebut dipengaruhi kehadiran peserta pada hari pertama namun tidak datang pada hari kedua dan jugasebaliknya atau bisa dikatakan 
peserta tidak hadir secara kontinu sehingga mempengaruhi hasil daripada pelatihan dan penyuluhan. Kegiatan Pelatihan dan Penyuluhan Higiene dan Sanitasi Bagi Penjamah Makanan dan MinumanKantin

SD/SMP/SMA/Sederajatmerupakan

kegiatan yang perlu dilakukan evaluasi.

Evaluasi adalah suatu pemeriksaan terhadap pelaksanaan suatu program yang telah dilakukan dan yang akan digunakan untuk dan mengendalikan pelaksanaan program ke depannya agar jauh lebih baik. Menurut Notoatmodjo, evaluasi dilakukan untuk menilai suatu program yang sedang atau sudah dilakukan, hasil dari evaluasi digunakan untuk perbaikan dana tau peningkatan program tersebut. ${ }^{4}$ Evaluasi yang dilakukan pada kegiatan ini menggunakan komponen 6M, yaitu material, money, machine, methode, man, dan measure.

Analisis yang dilakukan guna menjadi masukan atau pertimbangan dalam melanjutkan kegiatan tahunan tersebut.

Penelitian ini bertujuan untuk mengevaluasi kegiatan pelatihan dan penyuluhan higiene dan sanitasi makanan dan minuman bagi penjamah kantin SD/SMP/SMA/Sederajat yang diselenggarakan oleh Dinas Kesehatan Kota Malang guna menjadi masukan atau pertimbangan dalam melanjutkan kegiatan tahunan tersebut.

\section{METODE}

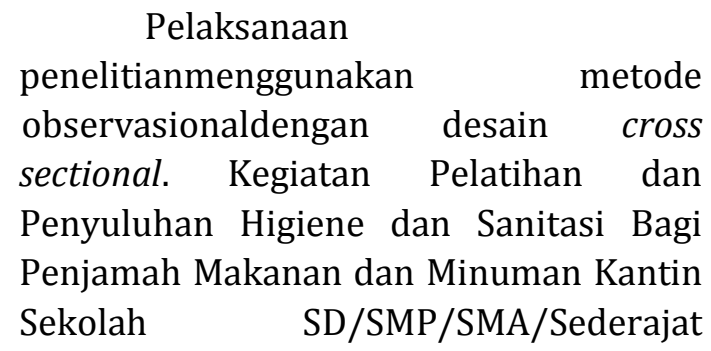

dilaksanakan di Dinas Kesehatan Kota Malang dengan jumlah pada hari pertama sebesar 39 peserta dan pada hari kedua sebesar 29 peserta. Teknik pengumpulan data menggunakan observasi dan wawancara. Analisis data menggunkaan analisis deskriptif yang hanya menghitung mean, median, dan mode.

\section{HASIL DAN PEMBAHASAN}

Pelatihan danPenyuluhan Higiene dan SanitasiMakanan dan Minuman bagi Penjamah Makanan Kantin Sekolah SD/SMP/SMA/Sederajat merupakan salah satu kegiatan tahunan Dinas Kesehatan Kota Malang.Tujuan dari kegiatan ini adalah meningkatkan pengetahuan dan pemahaman para penjamah makanan yang ada di kantin sekolah tentang peraturan dan perundang-undangan higiene sanitasi makanan. Sehingga harapannya adalah para penjamah makanan kantin sekolah dapat mengolah makanan yang dijajakan dan dijual dengan sebaik-baiknya dan sehat serta dapat memberikan rasa aman kepada konsumen kantin sekolah dari kalangan guru dan siswa, ataupun masyarakat umum. ${ }^{5}$ Kegiatan ini salah satu kegiatan yang memerlukan evaluasi karena penjamah makanan kantin sekolah merupakan seorang tenaga yang menjamah makanan mulai dari mempersiapkan, mengolah, menyimpan, mengangkut maupun dalam penyajian makanan. Pengetahuan, sikap, dan perilaku seorang penjamah makanan mempengaruhi kualitas makanan yang dihasilkan, apabila penjamah tersebut tidak memiliki pengetahauan, sikap, dan perilaku higiene dan sanitasi yang baik makan akan ada konsumen yang mengalami kesakitan. Pada hasil observasi kegiatan Pelatihan dan Penyuluhan Higiene dan Sanitasi 
Makanan dan Minuman bagi Penjamah Makanan Kantin Sekolah yang dilaksanakan di Dinas Kesehatan Kota Malang tanggal 14-15 Maret 2017 diketahui bahwa ada beberapa hal yang harus diperhatikan, diantaranya kurangnya sumber daya manusia seperti pemateri dan panitia yang bertugas, sebab pada tanggal tersebut Kepala Seksi maupun Staf Seksi Kesehatan Lingkungan, Kesehatan Kerja dan Olahraga yang lainnya mendapat tugas dinas luar sehingga hanya satu (1) Staf Seksi Kesehatan Lingkungan, Kesehatan Kerja dan Olahraga yang mendampingi dan sekaligus memberi materi penyuluhan, kemudian dibantu satu (1) pemateri dari seksi lain yang masih dalam lingkup Dinas Kesehatan Kota Malang, serta ditambah mahasiswa magang yang ikut membantu. Selain itu adapula kurang tepatnya sasaran, dimana pelatihan dan penyuluhan ini di khususkan untuk penjamah makanan kantin sekolah namun ada 5 orang yang bukan penjamah makanan melainkan guru dari sekolah tersebut.

Berikut Hasil dari pretest dan posttest Pelatihan dan Penyuluhan Higienedan Sanitasi Makanan dan Minuman bagi Penjamah Makanan Kantin Sekolah SD/SMP/SMA/Sederajat

Tabel 1. Hasil pretest dan posttest Pelatihan dan Penyuluhan Higiene dan Sanitasi Penjamah Makanan Kantin SD/SMP/SMA/Sederajat

\begin{tabular}{|c|c|c|c|c|c|c|c|c|c|c|c|}
\hline \multirow{2}{*}{ No. } & \multirow{2}{*}{ Nama* } & \multicolumn{2}{|c|}{ Hasil } & \multirow{2}{*}{ No. } & \multirow{2}{*}{ Nama* } & \multicolumn{2}{|c|}{ Hasil } & \multirow{2}{*}{ No. } & \multirow{2}{*}{ Nama* } & \multicolumn{2}{|c|}{ Hasil } \\
\hline & & pretest & posttest & & & pretest & posttest & & & pretest & posttest \\
\hline 1. & $\mathrm{~A}$ & 70 & - & 16. & $P$ & 40 & 60 & 31. & $\mathrm{EE}$ & 50 & 80 \\
\hline 2. & B & 40 & - & 17. & Q & 60 & 70 & 32. & $\mathrm{FF}$ & 10 & 20 \\
\hline 3. & $\mathrm{C}$ & 40 & - & 18. & $\mathrm{R}$ & 80 & 70 & 33. & GG & 50 & 70 \\
\hline 4. & D & 50 & - & 19. & S & 50 & 60 & 34. & $\mathrm{HH}$ & 60 & 50 \\
\hline 5. & $\mathrm{E}$ & 50 & 70 & 20. & $\mathrm{~T}$ & 60 & 70 & 35. & II & 40 & 70 \\
\hline 6. & $\mathrm{~F}$ & 70 & - & 21. & $\mathrm{U}$ & 60 & 60 & 36. & JJ & 30 & 60 \\
\hline \multirow{2}{*}{ No. } & \multirow{2}{*}{ Nama* } & \multicolumn{2}{|c|}{ Hasil } & \multirow{2}{*}{ No. } & \multirow{2}{*}{ Nama* } & \multicolumn{2}{|c|}{ Hasil } & \multirow{2}{*}{ No. } & \multirow{2}{*}{ Nama* } & \multicolumn{2}{|c|}{ Hasil } \\
\hline & & pretest & posttest & & & pretest & posttest & & & pretest & posttest \\
\hline 7. & $\mathrm{G}$ & 50 & - & 22. & V & 60 & 80 & 37. & KK & 30 & 60 \\
\hline 8. & $\mathrm{H}$ & 70 & - & 23. & W & 50 & 50 & 38. & LL & 50 & - \\
\hline 9. & I & 60 & - & 24. & $X$ & 50 & 70 & 39. & MM & 70 & 70 \\
\hline 10. & $\mathrm{~J}$ & 40 & 60 & 25. & $\mathrm{Y}$ & 70 & 80 & 40. & $\mathrm{NN}$ & 50 & - \\
\hline 11. & $\mathrm{~K}$ & 30 & - & 26. & Z & - & 50 & & Mean & 50 & 60 \\
\hline 12. & $\mathrm{~L}$ & 20 & 30 & 27. & $\mathrm{AA}$ & 40 & 50 & & Median & 50 & 60 \\
\hline 13. & M & 70 & 60 & 28. & BB & 60 & 30 & & Mode & 50 & 70 \\
\hline 14. & $\mathrm{~N}$ & 60 & 70 & 29. & $\mathrm{CC}$ & 50 & 50 & & & & \\
\hline 15. & 0 & 50 & 60 & 30. & DD & 60 & 80 & & & & \\
\hline
\end{tabular}

*disamarkan

Berdasarkan Tabel 1.pretest dan posttest Pelatihan dan Penyuluhan Higiene dan Sanitas Makanan danMinuman bagi Penjamah Makanan Kantin Sekolah SD/SMP/SMA/Sederajat di ketahui bahwa jumlah peserta yang mengikuti pretest di hari pertama sebanyak 39 orang dan posttest di hari kedua sebanyak 29 orang, perbedaan peserta yang mengikuti pretest dan posttest ini dikarenakan peserta yang hadir pada hari pertama tidak hadir pada hari kedua dan juga sebaliknya atau dikatakan peserta tidak hadir secara kontinu sehingga mempengaruhi tingkat keberhasilan kegiatan ini.

Berdasarkan pemaparan diatas ditinjau melalui komponen evaluasi 6M (material, money, machine, methode, man, dan measure) terdapat berbagai masalah dalam pelaksanaan kegiatan Pelatihan dan Penyuluhan Higiene dan Sanitasi 
Makanan dan Minuman bagi ] Nirmala Tri Kartika :Evaluasi Promosi dan Pelatihan ..... 132

Makanan

Kantin

SekolahSD/SMP/SMA/Sederajat

diantaranya sebagai berikut:

1. Material

Material dalam hal ini berupa handout materi.Padapelatihan dan penyuluhan ini tidak diberikan handout materi, hanya diberikan alat tulis untuk mencatat halhal yang di rasa penting selama penyampaian materi. Materi di paparkan dengan menggunakan powerpoint melalui $L C D$

\section{Money}

Money dalam hal ini berupa anggaran pelaksanaan kegiatan.Setiap tahunnya Dinas Kesehatan Kota Malang mendapat APBD dari Kota Malang yang dipergunakan untuk menjalankan setiap kegiatan.Anggaran yang diberikan per kegiatan pun berbeda, tergantung kebutuhan masing-masing.

3. Machine

Machine dalam hal ini berupa microphone.Pada pelaksanaan kegiatan pelatihan dan penyuluhan penjamah makanan dan minuman kantin sekolah microphone yang digunakan tidak berfungsi secara optimal, hal ini dikarenakan baterai pada microphone yang cepat sekali habis atau sering dilakukan pergantian baterai.

4. Methode

Methode dalam hal ini berupa ceramah.Pemaparan materi higiene dan sanitasi bagi penjamah makanan dan minuman disampaikan dengan metode ceramah.Pada dasarnya pelatihan diikutin dengan praktik namun pelatihan dan penyuluhan ini tidak disertai dengan praktik, hal ini pula yang menyebabkan peserta mengalami kebosanan.
Man dalam hal ini berupa peserta dan panitia. Pelatihan dan penyuluhan higiene dan sanitasi makanan dan minuman ini di khususkan untuk para penjamah kantin sekolah atau dapat dikatakan untuk bapak/ibu penjual di sekolah, bukan guru atau koordinator kantin namun pada kegiatan ini masih ada guru atau koordinator kantin yang datang.Kehadiran peserta tidak berlangsung secara kontinu, ada beberapa peserta yang datang di hari pertama tidak datang di hari kedua dan juga sebaliknya sehingga ada beberapa peserta yang hanya mengikuti pretest atau posttest.Panitia pada saat pelaksanaan kegiatan mendapatkan tugas dinas luar sehingga panitia yang bertugas di tempat hanya 2 namun panitia tersebut dibantu oleh mahasiswa yang sedang melakukan magang di Dinas Kesehatan Kota Malang sehingga dapat mengcover kekurangan panitia tersebut.

6. Measure

Measure dalam hal ini berupa hasil posstest.Pada kegiatan pelatihan dan penyuluhan dilakukan pretest dan posttest.Pretest dilakukan sebelum kegiatan di mulai tepatnya di hari pertama dan posttest dilakukan setelah kegiatan selesai yaitu di hari kedua. Hasil posttest menunjukkan keberhasilan kegiatan, semakin tinggi nilai posttest semakin banyak pula ilmu yang didapatkan namun kenyataannya ratarata nilai posttest sebesar 60 .

Berdasarkan hasil pemaparan komponen 6M diatas terdapat beberapa masalah yang akan diselesaikan, diantaranya: 
Tabel 2. Pemecahan Masalah Pelaksanaan Pelatihan dan Penyuluhan Higiene dan Sanitasi Makanan dan Minuman bagi Penjamah Kantin Sekolah SD/SMP/SMA/Sederajat

\begin{tabular}{lcl}
\hline No. & \multicolumn{1}{c}{ Masalah } & \multicolumn{1}{c}{ Pemecahan Masalah } \\
\hline 1. & Pelatihan dan penyuluhan ini dilakukan selama & Menyusun rundown acara dan memberikan \\
2 hari namun ada beberapa peserta yang & pada peserta pelatihan dan penyuluhan \\
hanya datang pada hari pertama dan kedua & ketika absen guna menghindari ketimpangan \\
sehingga peserta yang datang pada salah satu & kehadiran peserta dan juga agar peserta \\
hari hanya mengikuti prestest atau posttest & mengerti bahwa kegiatan tersebut harus \\
saja, dan dapat disimpulkan bahwa peserta & dihadiri secara kontinu (lampiran 1). \\
tidak datang secara kontinu & \\
\hline
\end{tabular}

2. Pemaparan materi higiene dan sanitasi bagi Pemateri Mempraktikan materi yang penjamah makanan dan minuman disampaikan, seperti contoh ketika materi disampaikan dengan metode ceramah._ proses masak memasak, pemateri

3. Pelatihan dan penyuluhan tersebut tidak mempraktikkan cara memasak air atau disertai dengan praktik, hal ini menyebabkan cara penambahan bahan tambahan peserta mengalami kebosanan. makanan yang benar.

4. Pelatihan dan penyuluhan higiene dan sanitasi Melakukan briefing pada koordinator makanan dan minuman di khususkan untuk puskesmas yang akan menyebarkan para penjamah kantin sekolah atau dapat di undangan kegiatan dengan tujuan agar katakan bapak atau ibu yang berjualan di tidak adanya lagi sasaran yang kurang kantin sekolah, bukan guru atau koordinator tepat. kantin di sekolah tersebut namun pada kegiatan ada beberapa guru atau koordinator kantin sekolah yang datang.

5. Panitia pada saat pelaksanaan kegiatan Mengkoordinasikan kegiatan sebulan mendapatkan tugas dinas luar sehingga sebelum dilaksanakan dengan satu bidang panitia yang bertugas di tempat hanya 2 bukan hanya pada seksi yang akan namun panitia tersebut di bantu oleh melakukan kegiatan, dengan kata lain mahasiswa yang melakukan magang sehingga membutuhkan kerjasama satu (1) bidang, dapat mengcover kekurangan panitia tersebut. hal ini dilakukan guna mengatasi apabila terjadi hal serupa, yaitu panitia pelaksana mendapat tugas luar dari atasan (lampiran 2). Koordinasi ini tidak hanya untuk kegiatan ini saja namun untuk semua kegiatan agar terjalin kekompokkan pada satu bidang.

\section{SIMPULAN DAN SARAN Simpulan}

Pelatihan dan Penyuluhan Higiene dan Sanitasi Makanan bagi PenjamahKantinSekolah merupakankegiatan yang mendapat perhatian untukdi evaluasi sebab terdapat 5 masalah yaitu sasaran

yang kurang tepat, panita penyelenggarayang kurang, kehadiran peserta yang tidak datang secara kontinu, pemaparan yanghanya menggunakan metode ceramah, dan tidak disertai praktik sehingga mengalami kebosanan. Kelima masalah 
tersebut berpengaruh terhadap hasil keberhasilan dan kegiatan tersebut. Alternatif pemecahan masalah tersebut meliputi menyusun rundown acara, pemateri mempraktikan matı Nirmala Tri Kartika :Evaluasi Promosi dan Pelatihan . 134 disampaikan, melakukan briefing pada koordinator puskesmas yang akan menyebarkan undangan, dan menyusun panitia penyelenggara yang melibatkan satu bidang.

\section{Saran}

1. Kepada Seksi Keslingkesjaor diharapkan laporan magang ini dapat digunakan sebagai pertimbangan dalam memecahkan masalah yang ada

2. Kepada mahasiswa magang selanjutnya untuk lebih proaktif dalam mengikuti rangkaian kegiatan magang dan memperkiran waktu yang tepat untuk memulai magang. Serta dimaksimalkan ilmu yang bisa diimplementasikan dan diterapkan sebaik mungkin.

\section{DAFTAR RUJUKAN}

1] Maharani, Nine Elissa. 2016. Hubungan Hygiene Sanitasi
Penjamah Makanan dengan Angka Kuman Makanan Jajanan Sekitar SMA Negeri 3 Wonogiri. Jurnal IKESMA Volume 12 Nomor 2, Hal.

2] Sitepu, E.L. 2015. Analisis Personal Higiene pada Penjual Makanan Tradisional Gado-Gado di Kelurahan Pisangan, Cempaka Putih dan Cireundeu Ciputat Timur Tahun 2015.Skripsi. Jakarta: Universitas Islam Negeri Syarif Hidayatullah

3] Kementerian KesehatanRepublik Indonesia. 2017. Pentingnya Peran Lintas Sektor Demi Wujudkan GERMAS. (Online)

(http://www.depkes.go.id/arti cle/view/17022700004/penti ngnya-peran-lintas-sektordemiwujudkan-germas.html) diakses tanggal 12 April 2017

4] Notoatmodjo, Soekidjo 2012. Metodologi Penelitian Kesehatan. Jakarta: Rineka Cipta

5] Dinas Kesehatan Kota Malang. 2016. Penyuluhan bagi Penjamah Makanan Kantin Sekolah. (Online) (http://dinkes.malangkota.go.i d/2016/02/18/penyuluhanbagipenjamah-makanankantinsekolah/) di akses 24 April 2017 